\title{
EGG QUALITY OF JAPANESE QUAIL IN SERBIA (Coturnix coturnix japonica)
}

\author{
M. Đukić Stojčić́ ${ }^{1}$ N. Milošević1 ${ }^{1}$ L. Perić ${ }^{1}$ I. Jajić1, N. Tolimir ${ }^{2}$ \\ ${ }^{1}$ Faculty of Agriculture, University of Novi Sad, Trg Dositeja Obradovića 8, 21000, Novi Sad, \\ Republic of Serbia \\ ${ }^{2}$ Institute for Science Application an Agriculture, Bulevar despota Stefana 68b, 11000, Belgrade, \\ Republic of Serbia \\ Corresponding autor: mirjana.djukicstojcic@stocarstvo.edu.rs \\ Original scientific paper
}

\begin{abstract}
In the last years Japanese quail (Conturnix coturnix japonica) is becoming more popular as a source of meat and eggs. Information on egg quality characteristics has been limited mostly to chicken eggs. The aim of this paper is to enhance the knowledge on the quality of quail eggs. In this study external and internal quality traits of quail eggs from three different commercial farms will be presented. For egg mass, shape index, shell thickness, shell mass no significant difference was found between farms. For yolk colour, yolk and albumen mass, statistically significant differences were found between the three farms. The difference in shell breaking strength between farms A and B was not significant and significant differences were found between eggs from farm C. Yolk, albumen and shell percentage were in the same relation as the mass of these parameters. The worst albumen quality was recorded in eggs from farm A. The parameters yolk colour, Haugh Unit and egg proportions (albumen, yolk and shell) do not differ between chicken and quail eggs. On the other hand, parameters which differ are egg mass (about five times smaller at quail eggs), shape index, shell breaking strength and shell thickness, which was to be expected. The external and internal egg quality traits of quail eggs from three farms in Serbia do not differ from the results of quality traits from other countries. On the other hand, this investigation contributes the development of science, because it includes some parameters, which have so far not been published in literature by other researchers from this area.
\end{abstract}

Key words: eggs, quail, internal and external quality traits

\section{Introduction}

In the last years Japanese quail (Conturnix coturnix japonica) is important as a laboratory animal, due to its easy maintenance, early sexual maturity, shorter 
generation interval, high rate of egg production, but Japanese quail is also becoming more popular as a source of meat and eggs (Punya Kumari, 2008). Eggs of most species of birds may have similarities in nutritional composition and potential food usage, however, information on egg quality characteristics and utilization of egg for food and other purposes have been limited mostly to chicken eggs. Chicken egg has been very well studied for its quality as well as for its composition, however such information are not so abundantly documented in other poultry species (Dudusola, 2010). Among many quality characteristics, external factors such as cleanness, freshness, egg weight and shell quality are important for consumer's acceptability of shell eggs, and interior characteristics such as yolk index, albumen index, proportions of egg components and chemical composition are also important for egg production industry (Song, 2000). Information on egg quality characteristics has been limited mostly to chicken eggs.

Because of the growing interest in consumption of quail eggs in our country, and due to the lack of recent investigations in this direction, the aim of this paper is to enhance the knowledge on the quality of quail eggs, and to show the quality of quail eggs in our surrounding. In this study external and internal quality traits of quail eggs from three different commercial farms will be presented.

\section{Materials and methods}

The experimental material comprised eggs of Japanese quail (Coturnix coturnix japonica) of laying type in their first year of production (between 25 and 30 weeks of age), derived from three commercial farms near Novi Sad. The quails in all three farms are kept in battery-cages under same conditions. The quails were fed ad libitum with the same complete commercial diets which can be found on the market, which is the reason why these three farms were chosen. The investigation of egg quality traits was carried out in the Department of Animal Science of the Faculty of Agriculture in Novi Sad. Examination of egg quality parameters was carried out on the random sample of 20 eggs per producer, one day after they have been collected from the farms. The following egg quality traits (external and internal) were assessed:

Egg weight (g), yolk weight (g), albumen weight (g), and shell weight (g) were measured with analytic scale with $0.01 \mathrm{~g}$ accuracy.

To determine the proportions of egg parts, each egg was carefully broken and shell separated. Eggs shell (not dried) was weighed and the relative weight calculated by relating the shell weight to the weight of the egg. An egg separator was used to separate the yolk from the albumen. Relative yolk weight was calculated in percentages by relating the yolk weight measured to the nearest gram to the whole weight of that particular egg and multiplied by 100 . The albumen weight was calculated by subtracting the yolk and shell weights from the whole 
egg weight. The albumen weight relative to the individual egg weight was calculated.

Yolk index (\%) was calculated according to the formula: Yolk index $=$ yolk height $(\mathrm{mm}) \times 100 \%$ / yolk width $(\mathrm{mm})$.

Haugh units were calculated according to the formula (Haugh, 1937): $\mathrm{HU}=$ $100 \log \left(\mathrm{H}+7.57-1,7 * \mathrm{M}^{0,37}\right), \mathrm{H}-$ average thick white height $(\mathrm{mm}), \mathrm{W}-$ egg weight $(\mathrm{g})$.

Shell breaking force was measured by an Egg Force Reader (Orka Food Technology Ltd, Israel). The stand of the device was modified for measuring quail eggs.

Egg yolk colour was determined according to Roche yolk colour fan (Vuilleumier, 1969).

Eggshell thickness ( $\mathrm{mm}$ ) was measured together with shell membranes at the equatorial part of the egg using a micrometer screw.

Based on obtained data, statistical analysis was done using ANOVA and Duncan post-hoc test (STATISTICA 8, Stat Soft Inc, 2007).

\section{Results and Discussion}

Table 1 presents results of egg quality traits. No significant differences were found in the egg weight and shape index between eggs derived from three producers.

The difference in shell breaking strength between farms A $(1.72 \mathrm{~kg})$ and $\mathrm{B}$ $(1.63 \mathrm{~kg})$ was not significant. However, a significant difference was found between eggs from farm $\mathrm{C}(1.05 \mathrm{~kg})$ compared to eggs from farms $\mathrm{A}$ and $\mathrm{B}(\mathrm{P}<0.05)$. No significant differences in shell thickness and shell weight between all three producers were found.

For egg weight, no significant difference was found between farms, but for yolk and albumen weight, statistically significant differences were found between the three farms. The weight of albumen was significantly different in all three farms. The difference between the highest and the lowest value was $1.01 \mathrm{~g}$ $(\mathrm{P}<0.05)$. Yolk, albumen and shell percentage were in the same relation as the weights of these parameters.

The most intensive yolk colour was recorded in eggs from Farm A (13.6points), whereas the eggs from quail in farm B had just 7.6 points (Roche). The yolk colour in Farm C was 10.9 points. Statistical differences were found between all three farms.

The worst albumen quality (Haugh Unit) was recorded in eggs from farm A (83.65). Statistical difference was found between that Farm A and Farms B and C. The average values of Haugh Unit in eggs from Farm B was 86.10 and from Farm C 87.93, and between those two farms no statistical difference was found. 
Table 1. Average values and standard deviation of external and internal egg quality traits of quail and average values of chicken eggs quality traits

\begin{tabular}{|c|c|c|c|c|c|c|c|}
\hline \multirow{4}{*}{ Parameters } & \multicolumn{7}{|c|}{ Producer } \\
\hline & \multicolumn{6}{|c|}{ Quail eggs } & \multirow{3}{*}{ Hen eggs * } \\
\hline & \multicolumn{2}{|c|}{ A } & \multicolumn{2}{|c|}{ B } & \multicolumn{2}{|c|}{$\mathrm{C}$} & \\
\hline & $\mathrm{X}$ & $\mathrm{Sd}$ & $\mathrm{X}$ & $\mathrm{Sd}$ & $\mathrm{X}$ & $\mathrm{Sd}$ & \\
\hline Egg weight (g) & 11,52 & 1,03 & 12,30 & 0,59 & 12,18 & 1,00 & $55-70$ \\
\hline Shape index (\%) & 77,37 & 2,43 & 77,51 & 3,79 & 75,11 & 2,89 & $61-86$ \\
\hline Breaking strenght $(\mathrm{kg})$ & $1,72^{\mathrm{a}}$ & 0,33 & $1,63^{\mathrm{a}}$ & 0,38 & $1,05^{\mathrm{b}}$ & 0,50 & $4--5$ \\
\hline Shell thickness (mm) & 0,196 & 1,780 & 0,201 & 1,610 & 0,186 & 1,350 & $0,32-0,35$ \\
\hline Shell weight (g) & 1,73 & 0,20 & 1,80 & 0,26 & 1,63 & 0,17 & $8-12 \%$ from egg \\
\hline Yolk weight (g) & $3,72^{b}$ & 0,42 & $3,42^{b}$ & 0,49 & $4,15^{\mathrm{a}}$ & 0,32 & \\
\hline Albumen weight (g) & $6,07^{\mathrm{c}}$ & 0,67 & $7,08^{a}$ & 0,38 & $6,4^{b}$ & 0,74 & \\
\hline Yolk colour (Roche) & $13,6^{\mathrm{a}}$ & 0,97 & $7,6^{\mathrm{c}}$ & 2,32 & $10,9^{b}$ & 2,18 & $1-15$ \\
\hline Haugh Unit & $83,65^{b}$ & 3,27 & $86,1^{\text {a }}$ & 3,02 & $87,93^{a}$ & 3,68 & $>70$ \\
\hline \multicolumn{8}{|l|}{ Egg proportions (\%) } \\
\hline Yolk & $30,00^{b}$ & 3,34 & $27,71^{\mathrm{c}}$ & 2,85 & $32,28^{a}$ & 1,95 & 31 \\
\hline Albumen & $55,15^{b}$ & 4,37 & $57,67^{\mathrm{a}}$ & 4,16 & $52,61^{\mathrm{c}}$ & 2,98 & 58 \\
\hline Shell & 14,85 & 1,72 & 14,62 & 1,78 & 15,09 & 1,72 & 11 \\
\hline
\end{tabular}

${ }^{\mathrm{a}-\mathrm{c}}$ Values within rows with no common superscript are significantly different $(\mathrm{P}<0.05)$

* Pavlovski et al. 2001, Milošević and Perić, 2011

Table 1 shows as well the mean values of several parameters of hen eggs (Milošević and Perić, 2011). It can be seen that the parameters yolk colour, Haugh Unit and egg proportions (albumen, yolk and shell) do not differ between chicken and quail eggs. On the other hand, parameters which differ are egg weight (about five times smaller at quail eggs), shape index, shell breaking strength and shell thickness, which was to be expected.

Chemical composition of same parameters of chicken and quail eggs are very similar. Our results show that average percentage of moisture, crude protein, crude fat, crude ash, $\mathrm{Ca}$ and $\mathrm{P}$ in yolk of chicken eggs are 51.35, 16.53, 28.12, 1.74, 0.13 and 0.47. In albumen of chicken eggs percentages of moisture and crude protein are 88.19 and 9.81. Average percentage of moisture, crude protein, crude fat, crude ash, $\mathrm{Ca}$ and $\mathrm{P}$ in yolk of quail eggs are 49.07, 16.76, 30.44, 1.71, 0.15 and 0.49 . In albumen of quail eggs percentages of moisture and crude protein are 88.15 and 10.47 . 
In this study, the average values that are determined are similar to the results reported by Nazligul et al. (2001), Ozcelik et al. (2002), Kul and Seker (2004), Nowaczewski et al. (2010) but different from results from Odunsi et al. (2007), Ipek et al. (2007), Punya Kumari et al. (2008), Dudusola (2009, 2010).

The mean egg weight in this experiment was similar to the results that were reported by Dudusola $(2009,2010)$. Nowaczewski et al. (2010), who analyzed egg weight changes according to age of the experimental birds, found that the value of this trait in week $25(10.91 \mathrm{~g})$ was smaller than in week $9(11.33 \mathrm{~g})$, but about $1 \mathrm{~g}$ higher than in results obtained by Odunsi et al. (2007), who evaluated three protein sources in the diets of growing and laying Japanese quails. The investigation from Punya Kumari et al. (2008) showed that mean egg weight from quail in $16^{\text {th }}$ week of production was 13.71 which is more than $1 \mathrm{~g}$ higher compared to our results.

Shape index, shell thickness, albumen weight, yolk weigh, Haugh Units and percentages of yolk and albumen were similar to the results reported by most researches (Nazligul et al., 2001; Ozcelik et al., 2002; Kul and Seker, 2004; Punya Kumari et al., 2008; Nowaczewski et al. 2010).

The value of shell breaking strength of quail eggs was between 1.05 and 1.72. This value was not compared to the results of other authors because these authors did not report the results of breaking strength. Generally it can be stated that the breaking strength is smaller compared to chicken eggs, which can as well be expected since the quail eggs have smaller weight and eggshell thickness.

The shell weight and percentage of shell in our investigation was bigger compared to the results of other authors (Odunsi et al., 2007; Ipek et al., 2007; Dudusola 2009, 2010, Nowaczewski et al. 2010), because the shell weight was measured directly after the shell was broken and separated, and the mentioned authors measured it after drying.

In results from Odunsi et al. (2007) the yolk colour was lighter and in range between 1.2 and 1.5 points (Roche). In investigation from Punya Kumari et al. (2008) the average yolk colour was 5.37, which is as well lighter than in our investigations, where the yolk colour was not uniform, and in the range between 7.6 and 13.6.

\section{Conclusion}

Generally it can be concluded that the external and internal egg quality traits of quail eggs from three farms in Serbia do not differ from the results of quality traits from other countries. On the other hand, this investigation contributes the development of science, because it includes some parameters, which have so far not been published in literature by other researchers from this area. Further investigations in the field of chemical composition are needed. 


\title{
Acknowledgment
}

Research was financed by the Ministry of Education, Science and Tehnological Development, Republic of Serbia, project TR 31033.

\section{KVALITET JAJA JAPANSKE REPELICE(Coturnix coturnix japonica)}

\author{
M. Đukić Stojčić, N. Milošević, L. Perić, I. Jajić, N. Tolimir
}

\section{Rezime}

Poslednjih godina japanska prepelica (Coturnix coturnix japonica) postaje sve više popularna kao izvor mesa i jaja. Informacije o karakteristikama kvaliteta jaja su uglavnom bila vezana za kokošija jaja. Cilj ovoga rada je da unapredi znanje o kvalitetu jaja prepelica. Predstavljeni su podaci o spoljašnjem i unutrašnjem kvalitetu prepeličjih jaja sa tri različite komercijalne farme. Parametari težina jaja, indeks oblika, debljina ljuske, težina ljuske se statistički značajno ne razlikuju između tri farme. Boja žumanca, težina žumana i belanca statistički su se razlikovale između sve tri farme. Nije bilo statistčki značajne razlike u sili loma između farmi A i B dok su se jaja sa farme C statistički bitno razlikovala u sili loma od fame A i B. Najlošiji kvalitet belanca zabeležen je u jajima sa farme A. Parametri boja žumanca, Hogove jedinice i procentualni udeo pojedinih delova jaja (belance, žumance i ljuska) se ne razlikuju bitno između kokošijih i prepeličijih jaja. Takođe hemijski sastav prepeličijih i kokošijih jaja je veoma sličan. Sa druge strane parametri koji se razlikuju a za koje je bilo i očekivati da će se razlikovati između kokošijih i prepeličijih jaja su težina jaja ( oko pet puta manja masa jaja prepelica u odnosu na kokošija jaja), indeks oblika, sila loma i debljina ljuske. Spoljašnji i unutrašnji kvalitet prepeličijih jaja iz tri različite farme u Srbiji se ne razlikuje od rezultata o kvalitetu prepeličijih jaja iz drugih zemalja. Ovo istraživenje doprinosi razvoju nauke o kvalitetu prepeličijih jaja jer obuhvata i neke parametre koji do sada nisu bili objavljeni u literaturi od strane drugih istraživača iz ove oblasti.

\section{References}

DUDUSOLA, I. O. (2010): Comparative evaluation of internal and external qualities of eggs from quail and guinea fowl. International Research Journal of Plant Science, 1(5) 112-115.

DUDUSOLA, I. O. (2009): Effects of Storage Methods and Length of Storage on some Quality Parameters of Japanese Quail Eggs. Tropicultura, 27 ( 1) 45-48. 
HAUGH, R.R. (1937): The Haugh unit for measuring egg quality. U.S. Egg Poultry Magazine, 43 552-553 and 572-573.

IPEK, A., CANBOLAT, O., KARABULUT, A. (2007): The Effect of Vitamin E and Vitamin $\mathrm{C}$ on the Performance of Japanese Quails (Coturnix Coturnix Japonica) Reared under Heat Stress during Growth and Egg Production Period. Asian-Aust. J. Anim. 20 (2) $252-256$.

KUL S., SEKER, I. (2004): Phenotypic Correlations Between Some External and Internal Egg Quality Traits in the Japanese Quail (Coturnix coturnix japonica). International Journal of Poultry Science, 3 (6) 400-405.

MILOŠEVIĆ, N. and PERIĆ, L. (2011): Tehnologija živinarske proizvodnje. Univerzitet u Novom Sadu, Poljoprivredni fakultet, Novi Sad, pp. 33-42.

NAZLIGUL, A., BARDAKCIOGLU, H.E., TURKYILMAZ, N.K., ORAL, D.C. (2001): The effect of cage density on egg weight, egg prodcution and feed consumpstion in Japanese quails. J. Fac. Vet. Med. Univ. 27 (2) 429-438.

NOWACZEWSKI, S., KONTECKA, H., ROSIÑSKI,A., KOBERLING, S., KORONOWSKI, P. (2010): Egg Quality of Japanese Quail Depends on Layer Age and Storage Time. Folia biologica, 58 3-4.

ODUNSI, A.A., ROTIMI, A.A., AMAO, E.A. (2007): Effect of Different Vegetable Protein Sources on Growth and Laying Performance of Japanese Quails (Coturnix Coturnix Japonica) in a Derived Savannah Zone of Nigeria. World Applied Sciences Journal, 3 (5) 567-571.

OZCELIK, M. (2002): The phenotypic correlations among some external and internal quality characteristics in Japanese quail eggs. Vet. J. Ankara Univ., 49 67-72. PAVLOVSKI, Z., HOPIĆ, S. and LUKIĆ, M. (2001): Housing systems for layers and egg quality. Biotechnology for Animal Science, 17, 197-200.

PUNYA KUMARIL, B., RAMESH GUPTA, B., GNANA PRAKASH, M., RAJASEKHAR REDDY, A. (2008): A study of egg quality traits in Japanese quails. J. Veterinary \& Animal Sciences 4 (6) 227-231.

SONG, K. T., CHOI, S. H., OH, H. R. (2000): A comparison of Egg Quality of Pheasant, Chukar, Quail and Guinea Fowl. Asian-Aus. J. Anim. Sci., 13 (7) 986990.

VUILLEUMIER, J.P. (1969): The 'Roche Yolk Colour Fan'-An Instrument for Measuring Yolk Colour. Poultry Science, 48: 767-779. 